\title{
For a Future Free of Violence: Moral Competencies As a Means of Emancipation and Self-Empowerment
}

\author{
Joanna Dutka \\ (Adam Mickiewicz University in Poznań, joannadutka7@gmail.com)
}

\section{Introduction}

In this paper I will explore the idea that protection from interpersonal violence is essential for making society more democratic, and in turn that education which focuses moral-democratic competencies is an appropriate means of helping people affected by interpersonal violence. I will specifically explain how the self-empowerment of people subjected to violence or endangered by the potential use of violence, can make a positive contribution to violence prevention. This selfempowerment goes hand in hand with the growth of competencies. I view this matter as complementary to the issue of preventing potential perpetrators from acting violently, by providing them with the opportunity to foster their own competencies.

I will also discuss gender-based violence and the situation of women affected by abuse, in order to support my claims with some empirical evidence. In this context, the type of violence I refer to is physical violence - acts of violence targeting the body of a person. Therefore, I will also explore the problem of violence prevention in the context of the struggle for women's emancipation and gender equality.

This paper will also refer to the idea of moraldemocratic competencies, following Georg Lind, who bases many of his ideas on the earlier works of his teacher, Lawrence Kohlberg. The view of democracy as way of life, which Lind supports in his work, corresponds to the vision of democratic relations in society which can be found in the writings of feminist political thinkers such as Iris Marion Young, Nancy Fraser and Ann Phillips.

My paper is organised as follows: Firstly, I will explain why I consider the important question concerning the growth of moral competencies as one which relates to the very conditions for the existence of democracy. Secondly, I will explain what is meant by moral-democratic competencies. Then I will try to show, briefly, how violence can be comprehended, and what impact it has on the lives of women. Lastly, I will explain why fostering moral competencies is important for persons subjected to violence. 


\section{Towards Life Free from Domination: A Brief Overview of Democracy from a Feminist Perspective}

Any society which aspires to be a democratic one has to be built on relations characterized by mutual respect, dialogical problem-solving, recognition of one another's autonomy, and the input of every person into shared existence (Young 2000)). Feminist political thinkers such as Ann Phillips suggest that interpersonal relations on the family and household level are the foundation for wider social and political life, including political freedom (1993). Gender relations within the family that are based on violence and coercion have a staggering effect on public life and the emancipation of women (comp. Fleming 1995). Relations in a democratic society need to be built on the basis of mutual respect, dialogue and recognition of one another's autonomy, as well as understanding the merit of arriving at consensus, rather than forcing one's own will on others.

Democracy, as a normative ideal, entails political equality, which means everyone should be included in the political life and decision-making of the society on equal terms. To fulfill this requirement, it must be ensured that no one is in the position to threaten others into certain proposals or outcomes, or prevent them from accessing the fora of opinion and decision-making (Young 2000, 23).

The route to achieving democracy - conceived of as being something more than merely a form of government - lies outside the traditionally comprehended political sphere (Phillips 1993). The idea stems from the model of the public sphere which presumes that the political system and will-formation should be rooted in opinion formation (Habermas 1996), in the so-called weak public spheres (Fraser 1992). From this model it follows that democratic relations - and the appropriate competencies which are necessary for sustaining them - have to have already been born and shaped (educated) in the places of everyday life - the kitchen, bedroom and nursery (Phillips 1993, 80). In other words, feminist thinkers stress the role of the domestic context not only for its specific significance for the lives of women in the private or personal sphere, but they also claim that the domestic context - the complex situation and relations at home - has paramount consequences for political life and influences the political system. The particular way of organizing social and interpersonal lives that constitute the family can be conceived of as a form of support system. Life within the family enables and/or limits the other activities a human being may want to undertake, including public and political activities. Familial relations and other close interpersonal relations are a foundation for other human activities, including political activities. That is why it is essential to keep close interpersonal relationships free of violence. Socially disadvantaged people, and women are such people even in modern democracies, are also more 
vulnerable in the context of interpersonal and intimate relationships ${ }^{1}$. In Nancy Fraser's terms, relations within the family that are equal and free from violence are necessary conditions for ensuring the participatory parity of women (comp. Fraser 1994, Fraser \& Honneth 2003).

In this view, democracy is something more than a system of the government, and it extends beyond the institutions of the political organs of a country, including the participation of citizens in the formation of public opinion. This entails that the functioning of the whole democratic system depends on the individuals who live in this system and their ability to act in accordance with the norms and rules that they have established so far (Nowak \& Cern 2008, 372). This ability in turn depends on the moraldemocratic competencies of all individuals. Only then can we talk about free cooperation, which is the foundation of the democratic way of life.

\section{What Are Moral Competencies?}

The term moral competencies refers to a person's ability to find solutions to problems and conflicts in accordance with inner moral principles, by means of discussion and deliberation, and without resorting to violence and deceit (Lind 2016, 13). In the short term, moral competencies refer to (a) the ability to quickly understand the complex moral circumstances and requirements of a particular situation. This means having an intuitive grasp of what universal moral principle should be applied in a given case. Moreover, (a) is followed by (b) arriving at decisions on issues concerning relations between the self and other people (Lind 2016, 28). This ability is inborn in its most basic, rudimentary state, but to match the complexity of modern society and interpersonal relationships it needs to be developed and educated (Lind 2016, 97).

Moral competencies can be extended by adding the perspective of coping with moral problems together. In this respect, it is appropriate to talk about moral-democratic competencies (Lind 2016, 29). For this reason, to the description of moral competencies (a) and (b), it is necessary to add (c) the ability to include the perspective of the other (for example, by asking for an opinion or advice) when making a decision or formulating the justification for it; and (d) the ability to acknowledge conflicting principles when formulating the justification for making a particular decision (comp. Lind 2016, 61). Moreover, as one can only speak about having competencies if

1 The vulnerability is a result of social and economical relations, fanatical dependence, sometimes limited access to institutions or lack of appropriate legal solutions to deal with the specificity of the problems of disadvantaged groups, but very often also a lack of information about the accessibility of help (comp. Fraser 1994, Bernardes 2014). 
they manifest themselves in practice, it is necessary to include (e) following that decision with action (Lind 20016, 61).

However, moral competencies are not moral orientations, nor particular sets of moral or ethical views, beliefs or principles an individual can follow. Those aspects of moral behavior, while they are not completely separate components, belong to different conceptual categories (comp. Lind 2016, 53-57).

Two components of moral-democratic competencies can be distinguished, namely: moral discursive competencies - which relate to the democratic dimension - dealing with moral issues together with others; and moral judgment competencies - which correspond to the individual dimension of competencies (comp. Lind 2016, 29). The moral judgment competence is the capacity to judge and decide in accordance with one's internal moral principles, which should always take into account the whole context of the situation that requires a solution, and then to act in accordance with the judgment made (Kohlberg 1964, 425; Lind 2016, 61). According to Immanuel Kant, an act of judging comes between the understanding of a general rule and the execution of this rule in practice (Kant, Reiss 1993, 61) ${ }^{2}$. This competence makes it possible to find appropriate moral norms to follow, depending on the situation that needs resolution.

The term 'moral-discursive competencies' describes an ability to communicate, in a way which would support the realization of the claims and interests of an individual, without resorting to violence or manipulation. Lind's understanding draws heavily on the Habermasian understanding of moral reasoning, which stresses looking for a consensus that can be obtained by means of argumentation, without the use of force or deception, as a way to solve conflicts. This includes avoiding the influence of power relations embedded in the context of everyday communication (Ling 2016, 61, Habermas 1996).

Moral competencies have affective and cognitive aspects, which means they are not limited to the conscious knowledge and reasoning of a subject, but they also include emotional intelligence or intuition, which we can characterize as feelings that fall under the scope of the concept of tacit knowledge, and which cannot be verbalized or subsequently transferred between individuals by means of language (Lind 2011,596).

Emotions and reasoning, particularly self-critical reasoning, keep one another in check. Often moral decisions are made mostly in accordance with our feelings, which allow us to act much sooner than through reasoning. In many circumstances reasoning can only occur as an afterthought to decision or even action (Haidt 2001). Self-conscious emotions, such as guilt, play an important part in the process of self-evaluation, providing feedback

${ }^{2}$ I am referring here to act of judging, not the origin or formation of the general rule. 
regarding our own actions (Tangney, Stuewig \& Mashek 2007, 21). Emotions are closely connected to epistemic and motivational states of mind, and it is not an understatement to say that they play a significant role in the process of moral decision-making, particularly in establishing preferences for certain actions over others (Bommatino 2014, 780). This means emotions are an important source of information for the self and are not disconnected from cognitive states.

It is important to note that human behavior, including moral behavior, even when it can be described as affective in character, is a result of complicated cognitive processes, and not some pre-existing, unchangeable reflexes (Lind 2016, 73). The significance of this premise for the issue presented here can be best seen in the fact that emotional and intuitive responses can be trained and shaped beforehand in the process of conscious, professionally trained thinking, and by taking part in respectful discussions. This is possible because of the feedback between the emotive state and conscious reasoning. Social experiences, discussion and working on hypothetical moral problems in abstraction from the context in which they are directly experienced contribute to the development of what can be called moral intuition - the immediate emotive response to problems, when they arise (Lind 2000, $2015 \& 2016$ ).

\section{Violence and the Impact on Gender Inequality}

In her book Violence, Mourning and Politics, Judith Butler provides insight into the nature of the experience of violence. In her account, being subjected to violence exposes one's vulnerability to other humans, the precarious situation of interpersonal contacts. Exposure of the self is given over to the will of another human being in a terrifying way. Even one's very existence can be threatened by the will of another in the act of violence (Butler, 2003, 28). Such experiences must have deep effects on the lives of individual subjects, and on the way they construct their selves and identities. This will be discussed in the following section.

I conceive of violence as a type of harm derived from misrecognition, a status injury, which takes a material guise (Fraser \& Honneth 2003, 76), emerging from social relations (Fraser 1996, 25) grounded in cultural patterns of representation, interpretation and communication (ibid. 7). Therefore violence as such is rooted in social relations, which means that in order to reduce the use of violence social relations need to be reshaped.

Violence always operates in wider frame of interactions within the relationship, and in the wider context of the society - acts of violence are not isolated (Wyatt 1994, 9). If intimate partner violence is widespread in the community, everyone, including abused women is more likely to find 
violence justifiable (Waltemauer 2012, 167). Abusers may believe they have the right to abuse, while victims and bystanders may think the victim deserves abuse. If the violence is seen as justifiable, victims or observers are less likely to get third party (for example, an institution) to intervene (Waltemauer 2012, 167-8). Gender-based violence can be conceived of as an expression of masculine power, and one of the main causes of women's oppression. What is more, violence often is supported by unwritten social rules, which have an even bigger impact on society than formal legislation, and are internalized in the process of socialization. Women are treated in a way that is thought to be suitable to their supposed nature and this treatment is not considered a violation, and at the same it time supports male sexual interests (Minhas 2009, 68).

Women who suffer violence frequently find themselves in complicated circumstances. Often, for many reasons, they simply cannot abandon their abusers. It is very likely that women subjected to their partner's violence are not on their own and need to consider someone else in their actions. They can be responsible for their children's wellbeing, taking care of elderly or disabled family members, or companion animals (Flynn 2000). They are faced with complex situation of a multifaceted crossdependence. They have to take into account such issues as financial conditions or living arrangements. They themselves may suffer from health problems or their decision may be limited by the need for care caused by long-term disability. Numerous other circumstances may come into play: feelings they may be harboring towards perpetrators, or social stigmas attached to victimization, dependence on welfare or broken homes (comp. Dutka 2015). Moreover, women who live in abusive relationships never know when they are next going to be subjected to violent treatment, therefore they have to make life-changing decisions when the clock is ticking.

The result of pre-existing relations of power on patterns of cultural interpretation, mentioned above, is that numerous factors can conceal the nature of violence even from the women who experience it themselves, effectively making it harder to identify a correct route of action. Gender relations within family based on violence and coercion have a staggering effect on public life and the emancipation of women.

Every person constructs a sphere of possible actions based on the interactions they have with other people. When influenced by experience, this sphere can shrink or expand (Honneth 1992, 190). Experience of violence, especially extreme forms of violence targeting the body of a person, such as rape and torture, significantly restricts the sphere of possible actiontaking. Let me note that domestic violence can be compared to torture, due to its intensity and repetitive nature (Bernandes 2014, 115). Apart from body harm and various financial costs, being subjected to violence creates fear and mistrust towards others, as well as towards one's own ability to 
judge and act morally, which in turn results in restricted contacts with others (Honneth \& Anderson 2005; Bernardes 2014, 116). People subjected to violence lose their sense of integrity and fall to the position where they no longer see themselves as someone whose traits and skills are worthy of respect (Honneth 1992, 194). The shame associated with victimization also prevents them from interacting with others as well as acting on their own behalf, which narrows the democratic dimension the life forms they are able to perform. their lives.

\section{Possible Countermeasures}

When asked about the most desirable outcomes of successful anti-violence programs, the women, partners or ex-partners of abusive men participating in the program mentioned above listed respectful relationships and an expanded sphere of action (Westmarland, Kelly \& Chalder-Mills 2010, 4). Fostering moral competencies can be very helpful for achieving such outcomes.

In the complicated situations described in the sections above, in which people affected by violence find themselves, judgment-making and decisionmaking skills as well as communicative competencies can be regarded as great assets. Such skills help women correctly assess relevant factors and solve problems involving conflicting principles and needs. As stated in the previous section, such skills, which essentially overlap with what is described as moral-democratic competencies, can be fostered and honed (comp. Lind 2009, 2015; 2016). What I would like to draw attention to here is the Konstanz Method of Dilemma Discussion ${ }^{\circledR}$ (or KMDD ${ }^{\circ}$ for short), created by an author previously cited in this paper, namely Georg Lind. This method proved to be an effective way to train judgment and discursive competencies, and to reduce aggression (Nowak \& Urbańska 2011, Lind $2016)^{3}$. Here, I would like to discuss the effects that participating in KMDD® sessions have on an individual. The effects of education, evident in the development of moral reasoning, can be objectively evaluated through the Moral Judgment Test (Lind 2011a, 575).

It has been proved that the use of the method helps people to communicate better with others and - what is particularly important here - to become more outgoing and speak up (Nowak \& Urbańska 2011, 91), as participants reduce their fear of others and their negative comments (Lind 2011b, 52). Participants learn how to find a proper measure between their own selfinterest and actively listening to others, respecting people with different opinions and seeing contact with them as an opportunity for personal

\footnotetext{
3 Wider account on the principles on which the KMDD $®$ is based and what the teaching with this method looks like can be found in multiple publications by Lind, most recently How to Teach Morality (2016).
} 
growth and an important source of inspiration (Lind 2011a, 583). Participation in KMDD ${ }^{\circ}$ sessions can aid participants with the understanding and construction of their emotions (Nowak \& Urbańska 2011, 91), which can prove to be very helpful in constructing and understanding their preferences and their identities. And what is even more profound in relation to gender-based violence, understanding of social retaliations is improved (comp. Prehn 2013, 16). Well-prepared discussion can help participants discoverer that they project false images on their interlocutors, which is an obstacle to successful communication and especially to seeking help from others (Lind 2011b, 48-49)

Therefore, such training can provide a countermeasure to the hopelessness and isolation connected to victimization. It can help victims expand the range of possible actions, which violence had limited, by improving their ability to judge and find solutions to the problems they suffer from, and to communicate with others, including the ability to seek advice and persuade, as well as construct and understand one's own emotions and needs. I am convinced that fostering moral competencies, aside from playing an important role in reducing the likelihood of men resorting to violence against their partners, can also help women escape victimization or revictimization. Expanding communicative and moral competencies provides people with moral democratic means to tackle their problems, hence, empowering them. Instead of being subjected to violence, gaining moral-democratic competencies expands the possible sphere of action that an individual constructs for herself.

Apart from finding solutions to difficult, morally and emotionally charged problems, well-developed moral-democratic competencies are invaluable for building new relationships founded on communication and mutual respect, or alternatively rebuilding former relationships. Additionally, the same competencies are important for many jobs that women may seek to support themselves with after leaving abusive relationships, and for public activity a possible means of taking actions in order to obtain influence or ownership of the policies and institutions that affect their lives.

\section{Why Concentrate on Women Subjected to Violence? - Towards Transformation}

Why concentrate so much on the victims of violent acts? Why not just concentrate on fostering the moral competencies of perpetrators/potential perpetrators, in order to prevent them from committing violent acts in the first place? After all, the perpetrators are the ones directly responsible for violence. Moreover, instances such as those known from the British Domestic Violence Perpetrators Program would suggest that getting help in learning 
how to communicate without the need to resort to violence is something that perpetrators themselves desire. Men participating in the survey during that program reported that they desire better awareness of their self and others, as well as better communication in their relationships (Westmarland, Kelly \& Chalder-Mills 2010, 7), all of which can be achieved by KMDD $®$ training.

There are several reason to employ KMDD $®$ alongside other existing methods. I will present two here: the first is its universality - every person can gain something for themselves from the KMDD®, regardless of what other more particular help they need. KMDD® can contribute to other therapies, for example therapies regarding the abuse of drugs and alcohol (comp. Lind 2016). The other significant reason, at least from feminist point of view, is that KMDD $®$ allows the participants to experience discussion free of domination. Other programs, while helping to mitigate the physical and psychological abuse from relationships, fell short when it came to removing the aspect of domination from the relationship, which may lead to a return to the cycle of abuse further down the line (comp. Domestic Violence Perpetrators Program: Westmarland, Kelly \& Chalder-Mills 2010).

The wider description of KMDD® can be found in Georg Lind's How to Teach Morality (2016). A session includes: the presentation of a short dilemma (in oral and written form), dilemma clarification, time to prepare arguments, and a main discussion that includes a presentation of the arguments and later evaluation. There are only two rules for the participants: 1) Anything can be said, but no person can be judged negatively or positively; and 2) the ping-pong rule: the person who spoke the last picks a person who is to speak next from the opposite side (self-moderating discussion). The teacher's role is to signal when the rules are broken. The structure of a KMDD® session follows phases of challenge and phases of support, which are carried out alternately to ensure the optimal concentration levels of the participants (Lind 2016, 165), and this requires significant competencies and experience from the teacher, despite the apparent simplicity of the method. The use of the method by competent teachers is proven to reduce aggression (Nowak \& Urbańska 2011, Lind 2016).

I do not deny the need to teach people how to achieve desired outcomes in communication with others without resorting to violence, which is something that many people, not only men, cannot do. I believe this is one of the reasons people use violence when they find themselves in the position of power, which men in relationships often do, due to the gender bias in our society.

I am far from blaming the victims for their situation. However, I have an idea stemming from the lecture on Feminist Theory by Bell Hooks, in short: women already have the power to make changes, they just do not realize it and do not know how to make use of it (Hooks 1984, 83-93). With 
regard to the issue addressed in this paper, women already have the power to do something against violence and their own victimization. However, they obviously lack something that would enable them to take action. That something may be knowledge. There are numerous accounts of women not knowing their rights, or where to go for help, believing that they cannot do anything about their situation or even that they should be passive. But there is something else that women can be missing, namely competencies. That is why there is a need to foster the development of their moral competencies, so that they can gain the tools to tackle their problems and to work on their personal growth, and thereby find a viable solution.

Moreover, violence clearly exists. We cannot undo it and its consequences. It is not enough to merely prevent violence from being used in the future. To successfully reduce violence, we must ensure that people who are subjected to it have a way out, and that they will not return to the cycle of victimization.

I am convinced that fostering moral competencies, aside from playing an important role in reducing the likelihood of men resorting to violence against their partners, can also help women escape victimization or revictimization. This is important, because in order to be seen and treated as peers in society, individuals must be seen as agents of their own emancipation (Bernardes 2014, 125). Therefore, it is of key importance with regard to the lives of women affected by the problem of intimate partner and domestic violence, that they themselves should be empowered. Expanding communicative and moral competencies provides people with the moral democratic means to tackle their problems, and hence empowers them.

Educating and fostering the moral-democratic competencies of women should be comprehended as a part of a public policy, which should be regarded as a complementary to creating appropriate strategies and institutions designed to provide women help so that they can get out of hard situations, because these strategies and institutions alone do not suffice. In many respects, the institutional protection of disadvantaged people within interpersonal relationships does not function well. Exerting control over a person, and the "micromanagement" of someone's life, does not empower that person and may hinder her in building her own relationships and creating life as she pleases (comp. Fraser \& Gordon 1994, 230). Of course, that does not mean that institutions that are entitled to interfere with interpersonal relationships for the sake of protection should cease to exist. Indeed, without external support personal empowerment may not be regarded as a strong enough factor for escaping from violence, but on the other hand external support alone is not enough either, if the social structures justifying the use of violence need to be changed. The real change should be understood here in terms of transformation. This kind of change entails an individual change in the personal structure of attitudes, beliefs and 
affects, as well as in the moral judgments which are based on them, and the dispositions to act in accordance with autonomously formulated judgments in diverse situations - in other words, a transformation of moral-democratic competencies which enables discursive problem-solving and, on this basis, motivates people to act respectfully towards a discursively achieved solution (comp. Cern 2014, 16). And external support is needed to provide the possibilities for, and assistance with, the said transformation.

\section{To Conclude:}

Violence against women is an inherent part of the structure that our society is built on, and it will not disappear unless this structure is reformed and transformed. Widespread violence against women significantly hinders them in their attempt to achieve equality. It is an obstacle to achieving democratic social relations between people. Fostering moral competencies has the potential to both prevent violence and help women victimized by their partners to gain new possibilities.

In the current situation, in which the rights of women are caught up in political games, it is perhaps more important than ever before to consider violence prevention as a crucial factor for social transformation. A person with better-developed moral democratic competencies is better equipped to resolve conflicts without the use of violence, even when confronted with confusing cultural beliefs and social mores. Educating women and fostering their moral-democratic competencies should be understood as a part of a public policy which should be regarded as a complementary to creating appropriate strategies and institutions designed to provide women help, so that they can escape from difficult situations, because these strategies and institutions alone do not suffice.

Providing people subjected to violence with opportunities to develop their moral-democratic competencies equips them with tools not only to reshape relationships with their family units, but also with society as a whole. Moreover, even though I have mostly addressed situations in which women are subjected to abuse from men, any person, even in the reverse situation can benefit from the opportunity to foster their own moral competencies, making them universal.

\section{Literature:}

Bartlett, K. T. 1990. Feminist Legal method. Harvard Law Review, 103 (4), 829-888. doi: 10.2307/1341478.

Belknap, J. \& Melton, H. 2005. Are Heterosexual Men Also Victims of Intimate Partner Abuse?, National Electronic Network on Violence Against Women. 
http://www.xyonline.net/sites/default/files/Belknap,\%20Are\%20he terosexual\%20men\%20also.pdf (on December 20, 2016)

Bernardes, M. N. 2014. Domestic Violence and Gender Oppression: an Analysis of Brazilian Law in Light of a Theory of Democratic Justice, in M. Zirk-Sadowski, B. Wojciechowski, K. M. Cern (eds) Legal and Communication Strategies towards the Recognition of Minority Groups. Farnham: Ashgate, Chapter 9, pp. 113-128.

Cern, K. M. 2014. Counterfactual Yardstick. Normativity, SelfConstitutionalization and Public Sphere. Bern - New York: Peter Lang.

Dutka, J. 2014. Misrecognized Violence Against Woman and Perpetrated by Woman. Seeking for Remedies. Ethics in Progress, 5(2), 187-203. doi: 10.14746/eip.2014.2.13

Fraser, N. \& Gordon, L. 1994. Genealogy of Dependency. Tracing the Key Words of the US Welfare State. Signs: Journal of Women in Culture and Society, 19(2), 309-336. https://doi.org/10.1086/494886

Fraser, N. \& Honneth, A. 2003. Redistribution or Recognition? A PoliticalPhilosophical Exchange. London: Verso.

Fleming, M. 1995. Women and the Public Use of Reason, In J. Meehan (ed.) Feminist Read Habermas. Gendering the Subject of the Discourse. New York - London: Routledge.

Flynn, C. P. 2000. Battered Women and Their Animal Companions: Symbolic Interaction Between Human and Nonhuman Animals. Society \& Animals, 8(2), 99-127. doi: 10.1163/156853000511032 (retrieved on December 17, 2016).

Gilligan, C. 1994 (or. 1982). In a Different Voice, Psychological Theory and Women's Development. Cambridge, Mass.: Harvard University Press.

Gilligan, J. 2003. "Shame, Guilt, and Violence". Social Research, 70(4), 114980.

Habermas, J. 1979. Moral Development and Ego Identity, in Communication and Evolution of Society. Tr. Thomas McCarthy. Boston: Beacon Press, pp. 69-94.

Habermas, J. 1996. Between Facts and Norms. Contribution to Discourse theory of Law and Democracy. tr. W. Rehg. Cambridge, Mass.: The MIT Press.

Tarry, H. \& Emler, N. 2007. Attitudes, Values and Moral Reasoning As Predictors of Delinquency. British Journal of Developmental Psychology, 25(2), 169-183. doi: 10.1348/026151006X113671

Haidt, J. 2001. The Emotional Dog and Its Rational Tail: A Social Intuitionist Approach to Moral Judgment. Psychological Review, 108(4), 814-34. http://dx.doi.org/10.1037/0033-295X.108.4.814

Honneth, A. 1992. Integrity and Disrespect: Principles of a Conception of Morality Based on the Theory of Recognition. Political Theory, 20(2), 187-201. https://doi.org/10.1177/0090591792020002001 
Honneth, A. \& Anderson, J. H. 2005. Autonomy, Vulnerability, Recognition, and Justice. In J. Chrisman \& J. Anderson (eds) Autonomy and the Challenges to Liberalism: New Essays. New York: Cambridge University Press, pp. 127-149.

Hooks, B. 1984. Feminist Theory. From Margin to Centre. Boston: South End Press.

Lim, B. H. (Phylice), Valdez, C. E., \& Lilly, M. M. 2015. Making Meaning Out of Interpersonal Victimization: The Narratives of IPV Survivors. Violence Against Women, 21(9), 1065-86. doi: $10.1177 / 1077801215590670$ (retrieved on December 10, 2016).

Lind, G. 2000. The Importance of Role-Taking Opportunities for SelfSustaining Moral Development. Journal of Educational Research, 10, 2-24. Retrieved from: http://www.uni-konstanz.de/FuF/SozWiss/fgpsy/ag-moral/pdf/Lind-2000_Selfsustaining-moral-development.pdf

Lind, G. 2008. The Meaning and Measurement of Moral Judgment Competence: A Dual-Aspect Model. In D. Fasko \& W. Willis (eds) Contemporary Philosophical and Psychological Perspectives on Moral Development and Education. Cresskill, NJ: Hampton Press, pp. 185220 .

Lind, G. 2009. Moral ist lehrbar, München: Oldenbourg Schulbuchverlag.

Lind, G. 2011a. Moral Competence and the Democratic Way of Living. Europe's Journal of Psychology, 7(4), 569-596. https://doi.org/10.5964/ejop.v7i4.153 (retrieved on December 10, 2016).

Lind, G. 2011b. Moral Education: Building On Ideals and Fostering Competencies". Contemporary Issues in Education, 2(1), 45-59. http://www.uni-konstanz.de/ag-moral/pdf/Lind-2011_Moral Education_CIE.pdf (retrieved on December 7, 2016).

Lind, G. 2012. Moral Competence and Democratic Ways of Life, In W. G. Weber, M. Thoma, A. Ostendorf, \& L. Chisholm (eds) Democratic Competences and Social Practices in Organizations. Wiesbaden: Springer Verlag, pp. 62-85.

Lind, G. 2015. Favorable Learning Environments for Moral Competence Development. A Multiple Intervention Study With 3.000 Students in a Higher Education Context. International Journal of University Teaching and Faculty Development, 4(4). https://www.novapublishers.com/catalog/product_info.php?produc ts_id=53411 (retrieved on November 11, 2016).

Lind, G. 2016. How to Teach Morality. Promoting Deliberation and Discussion, Reducing Violence and Deceit. Berlin: Logos Verlag.

Kelly, L. \& Westmarland, N. 2015. Domestic Violence Perpetrator Programmes Steps To Change Executive Summary. http://respect.uk.net/wpcontent/uploads/2015/01/Project-Mirabal-executive-summary- 
EMBARGO-00.01-MONDAY-12-JANUARY-2015.pdf (retrieved on January 23, 2015).

Minhas, S. F. 2009. The Politics of Rape and Honor in Pakistan. In L. M. Cuklanz \& S. Moorti (eds) Local Violence Global, Global Media. Feminist Analyses of Gendered Representation. New York: Peter Lang Publishing, pp. 65-78.

Nowak, E. \& Cern, K. M. 2008. Ethos $w$ życiu publicznym. Warszawa: Wydawnictwo Naukowe PWN.

Nowak, E. 2012. Experimental Ethics, A multidisciplinary Approach. Münster Berlin: LIT.

Nowak, E.. (2013). Democracy Begins in the Mind. Developing Democratic Personality, in E. Nowak, D. Schrader, \& B. Zizek (eds) Educating Competencies for Democracy. Frankfurt/M. - Bern - New York: Peter Lang Publishing, pp. 399-416.

Nowak, E. \& Urbańska, A. 2011. "Can Konstanz Method of Dilemma Discussion Support an Emotional Cognitive Balance in Aggressive Juveniles?". Journal of Strategy and Decision Making, Fall Autumn, 8593. http://www.uni-konstanz.de/ag-moral/pdf/Nowak_Urbanska2013_Aggression_KMDD.pdf (retrieved on December 10, 2016).

Philips, A. 1993. Democracy and Difference. Cambridge: Polity Press.

Prehn, K. 2013. Moral Judgment Competence. A Reevaluation of the Dual Aspect Theory Based on Recent Neuroscientific Research. In E. Nowak, D. Schrader, \& B. Zizek (eds) Educating Competencies for Democracy. Frankfurt/M. - Bern - New York: Peter Lang Publishing, pp. 9-22.

Schmidt, B. E. \& Schröder, I. W. (eds) 2001. Anthropology of Violence and Conflict. European Association of Social Anthropologists: Routledge.

Tangney, R. W., Price, J., Stuewig, J., \& Mashek, D. J. 2007. What's Moral About the Self-Conscious Emotions. In J. L. Tracy, R. W. Robins, \& J. Price Tangney (eds) The Self-Conscious Emotions: Theory and Research. New York: Guldfor Press, pp. 21-37. https://zodml.org/sites/default/files/\%5BJessica_L._Tracy\%2C_Rich ard_W._Robins\%2C_June_Price_T.pdf\#page=39 (retrieved on January 20, 2017).

Urbańska-Krusik, A. 2011. Etyka dyskursu w resocjalizacji: nowe metody pracy z grupami podwyższonego ryzyka. Teraźniejszość - Człowiek Edukacja, 3(55), 97-106. http://bazhum.muzhp.pl/media//files/Terazniejszosc_Czlowiek_Edu kacja_kwartalnik_mysli_spoleczno_pedagogicznej/Terazniejszosc_Czl owiek_Edukacja_kwartalnik_mysli_spoleczno_pedagogicznej-r2011-tn3_(55) (retrieved on December 12, 2016). 
Westmarland, N., Kelly, L., \& Chalder-Mills, J. J. 2010. What Counts as Success? London: Respect. http://www.who.int/mediacentre/factsheets/fs239/en/ (retrieved on January 20, 2017).

Young, I. M. 2000. Inclusion and Democracy. New York: Oxford University Press Inc. 


\author{
Joanna Dutka \\ (Adam Mickiewicz University in Poznań, joannadutka7@gmail.com) \\ For a Future Free of Violence: Moral Competencies As a Means of \\ Emancipation and Self-Empowerment
}

\begin{abstract}
The paper explores the role of fostering moral-democratic competencies for violence prevention, in particular in the relation to genderbased, intimate partner and domestic violence. Additionally, significant emphasis is placed on the prevention of revictimisation. Violence prevention is framed with regard to the political importance of violence-free homes and intimate relationships for the empowerment of women. The paper refers to the complex situation of women subjected to abuse and the effects of violence on an individual. As a countermeasure, the paper proposes the development of moral-democratic competencies, and recommends the Konstanz Method of Dilemma Discussion ${ }^{\circledR}$ as an example of an efficient method to accomplish this task.
\end{abstract}

Key words: moral-democratic competencies, $\mathrm{KMDD}$, violence against women, intimate partner violence, violence prevention, revictimisation

Ethics in Progress (ISSN 2084-9257). Vol. 8 (2017). No. 1, Art. \#14, pp. 225-240.

Creative Commons BY-SA 3.0

Doi: 10.14746/eip.2017.1.14 